\title{
Enhancing organizational performance through information technology: An \\ organizational and social strategic context
}

José Luís Martinho, Ph.D.

ISEC - School of Engineering

Polytechnic Institute of Coimbra

Rua Pedro Nunes - Quinta da Nora

3030-199 Coimbra - Portugal

Email: martinho@isec.pt

Carlos F. Gomes, Ph.D.

University of Coimbra - School of Economics

ISR-Institute of Systems and Robotics

Av. Dias da Silva 165

3004-512 Coimbra - Portugal

Email: cfgomes@fe.uc.pt

Mahmoud M. Yasin, Ph.D.

East Tennessee State University

Department of Management \& Marketing

P.O. Box 70625

Johnson City, TN 37614

Email:mmyasin@ETSU.edu

This is a post-print (i.e. final draft post-refereeing) of an article published in International Journal of Business Information Systems (ISSN: 1746-0972), available online at:

https://www.inderscienceonline.com/doi/pdf/10.1504/IJBIS.2015.070887

Citation: Martinho, J. L., Gomes, C. F., \& Yasin, M. M. (2015). Enhancing organisational performance through information technology: an organisational and social strategic context. International Journal of Business Information Systems, 20(1), 95-115. 


\title{
Enhancing organizational performance through information technology: An organizational and social strategic context
}

\begin{abstract}
Motivated by the increasing significance of information technology (IT) in today's open system organizations, the objective of this research is to uncover the relationships between business executives and their IT counterparts, which are essential toward improving organizational performance. In the process, a structural equation modelling is utilized to analyse the responses of a sample of hundred and forty-one (141) Portuguese executives. The results of testing the nine research hypotheses tend to underscore the significance of the trust between business and IT executives. Such trust is capable of fostering an organizational culture, which is conducive to the enhancement of the organizational performance. The ability of these business and IT executives to work together cultivates a knowledge domain, which generates effective solutions and applications to organizational problems. In turn, this contributes to improving the competitive performance of the organization.
\end{abstract}

Keywords: IT-business relationship; shared domain knowledge; IT-business social alignment; organizational performance. 


\section{Enhancing organizational performance through information technology: An organizational and social strategic context}

\section{INTRODUCTION}

Not a long time ago, business organizations, which adhered to the closed system business model, considered information as a cost of doing business rather than a potential organizational resource. As such, a data perspective on the importance of information left organizations searching for the best way to store the organizational aggregated data efficiently. This business era was marked by the dominance of a technical and physical data storage consideration, as opposed to a logical and useful applications consideration. In short, technical hardware and software specialists dominated the information management functions of business organizations.

In this context, the business user has very little to contribute to the computing function management of organizational information and related applications. The prevalent attitude of technical information specialists was "we designed it; they should find a way to use it". Needless to say that such era was marked by lack of cooperation and mistrust, between business users and IT specialists. Neither side spoke the language of the other, nor put forth an effort to understand its needs and constraints. As a result, the organization, as a whole suffered from the lack of innovation in relation to information solutions and applications needed to promote organizational performance.

The advent of inexpensive hardware and friendly software, coupled with advances in telecommunications technology facilitated the organizational shift toward the open system business model by most organizations. The open system orientation stressed organizational connectivity, both internally and externally. As such, data 
became a valuable resource, as it was transferred into information that enriched organizational knowledge. The domain of this shared knowledge slowly expanded to include employees, customers, suppliers, and other environmental entities. In turn, this organizational knowledge was utilized to facilitate the creation of information solutions and applications.

In order to utilize information and the resulting knowledge efficiently and effectively, innovative business applications targeted at markets, customers, and even competitors needed to be designed and implemented (Althonayan \& Sharif, 2010; Goyal, 2012). Such effort was not feasible without the full cooperation between IT executives and their business counterparts. In this context, technical/physical design issues and constraints needed to be understood by business users. On the other hand, IT specialists needed to understand business applications and their organizational operational and strategic values.

As competition intensified, organizations were called upon their IT capabilities to create innovative applications in order to outperform the competition in the marketplace. Information and knowledge were beginning to be used strategically in order to gain as well as sustain competitive advantage. As such, trust, in these innovative applications and the specialist that created them, was needed before there implementation (McLeod \& Pippin, 2012).

The success, or lack off, of the strategic utilization of information and knowledge was contingent on the degree of cooperation, synergy, and trust between the IT executives and their business counterparts. Such cooperation was needed in order to establish the trust required for having a win-win relationship through IT business alignment. The resulting win-win approach to the relationships between IT executives 
and their business executives facilitated the creation of a shared organizational knowledge domain. This shared knowledge domain was used to create innovative solutions and applications designed to enhance organization performance.

In this context, the win-win relationship between the IT executives and their business counterparts eliminated the sub-optimization orientation of the closed system business model. Under the closed system business model orientation, technical considerations often were in conflict with the effectiveness of the business applications.

The literature which dealt with the different aspects of the relationships between IT and business activities and applications has been forthcoming. However, empirical research exploring the interdependencies among the different relationships, which define the cooperation between IT activities and business tasks, have been slow in forthcoming (Karahanna and Preston, 2013). This is especially true when such relationships are viewed from an open system organizational perspective. Such a perspective tends to emphasize a win-win outcome with regard to the utilization of information technology in the context of improving organizational performance.

The study at hand is part of a stream of research aimed at understanding the dynamic relationships between IT activities and resources, and business applications and solutions. The segment of this research presented in this study focuses on the different relationships between both IT and business executives. To that end, structural equation modelling is used to assess the nature of the relationships among constructs derived from literature. These constructs include trust, business interaction, and social IT-business alignment. The impact of these relationships on organizational performance is given special attention. 
The open system business model depicted in Figure 1 is used to guide this study. As shown in the figure, today's business organizations, as open systems, are constantly aspiring towards improving their performance in order to stay competitive in a highly dynamic and technologically changing environment. Information technology has the potential to contribute to this ultimate goal. For such end to be achieved effectively, business and IT executives must jointly cooperate to create an organizational culture, which is conducive to effective utilization of information technology.

\section{Insert Figure 1}

Motivated by the discussion above, the objective of this study is to shed some light on the important relationships and interactions between business and IT executives in the road towards better utilization of IT know-how and resources. The study utilizes a survey of hundred and forty-one (141) Portuguese business executives representing different industries. Understanding the different facets of the relationships related to the effective utilization of organizational informational resources has significant practical value to today's organizations. This understanding has the potential to promote the effective implementation end utilization of IT solutions and applications, which in turn may lead to a strategic competitive advantage for the organization. The cooperation and trust between business and IT executives are critical in this context. Therefore, organizations should invest in reengineering their cultures in order to foster a win-win relationship between the IT experts and executives, and their business users and executive counterparts.

The study at hand is a modest contribution in this direction as it emphasizes such trust and cooperation within the context of the open system integrated organizational 
orientation. Previous studies have dealt with the issues and relationships addressed here either discretely or from a closed system orientation.

\section{BACKGROUND}

The influence of information technology on organizational performance has been a research topic of interest in the literature. However, no consensual results relating to the nature of this influence have been reached (Dehning \& Richardson, 2002; Keramati \& Behmanesh, 2010; Masli, Richardson, Sanchez, \& Smith, 2011). Business organizations have the potential to achieve a competitive advantage by mobilizing and combining organizational resources and capabilities (Barney, 1991; Wade \& Hulland, 2004). These resources, usually intangible in nature, should be valuable, rare, difficult to imitate, and non-substitutable. A unique combination of IT, resources, and know-how blended with other related organizational resources could be the key to improving the strategic competitiveness of business organizations (Bharadwaj, 2000).

Executives from various functional areas have different and sometimes conflicting views of organizational reality. Such differences could lead to a gap between the information technology function and other business functional areas (Curry, Marshall, \& Kawalek, 2014). This gap could be attributed to the misunderstanding and mistrust between the concerned executives of these different functional areas. The ITbusiness relationships are intangible organizational resources identified in the literature. These relationships, however, are often essential to delivering superior organizational performance (Karahanna \& Preston, 2013; Ross, Beath, \& Goodhue, 1996). In this context, a strong relationships between IT executives and business executives are strategically important to the survival of the organization (Rockart, Earl, 
\& Ross, 1996; Siurdyban, Svejvig, \& Møller, 2012; van den Hooff \& de Winter, 2011). Some key factors, such as the partnerships and mutual understanding between IT and business executives, and the strength of the IT-business relationships were identified as possible drivers to improving the competitiveness of business organizations (Bharadwaj, Sambamurthy, \& Zmud, 1999; Feeny \& Willcocks, 1998). The IT assimilation by the organization appears to be improved by the strong interaction between IT executives and business executives (Armstrong \& Sambamurthy, 1999; Cereola, Wier, \& Norman, 2013). The IT-business relationships tend to enhance the social and organizational cultural alignment. In the process, these relationships promote a positive influence on organizational performance (Bhatt \& Grover, 2005; Karahanna \& Preston, 2013; Kearns \& Lederer, 2003; Luftman \& Brier, 1999).

The fusion of business knowledge, with IT knowledge, is also an intangible organizational resource that seems to promote the strategic utilization of information technology (Chao \& Chandra, 2012; Peppard \& Ward, 2004). The interaction between IT and business executives, along with the integration of their knowledge, could be enhanced when they have shared domain knowledge (Madhavan \& Grover, 1998). According to Reich \& Benbasat (2000), the shared domain knowledge between IT and business executives entails their ability to understand and participate in the others' key management processes, and respect their unique contributions. The shared domain knowledge between IT and business executives could be viewed as an important driver of organizational performance improvement, through the creation of a mutual understanding and the utilization of a common language between them (Chan, Sabherwal, \& Thatcher, 2006; Nelson \& Cooprider, 1996; Reich \& Benbasat, 2000). 
The literature reviewed included several survey-based studies, which examined the above concepts and relationships (Table 1). However, in each of these studies the lack of some important variables was noted. As such, an exploratory empirical investigation, which incorporates and integrates much of the identified relevant variables, is justified. This is true, especial in light of the open system business model orientation utilized by today's business organizations. In such a business model orientation, information is considered the basis of the openness of the system. Therefore, understanding the nature and scope of the relationship among information and business related variables are essential towards the effectiveness of organizational performance.

\section{Insert table 1}

In this context, the objective of this study is to shed some light on the nature of the interactions between IT and business executives. In the process, the impact of such interactions on organizational performance is examined. The extent of interactions among three dimensions: IT business relationships, shared domain knowledge, and ITbusiness social alignment are especially emphasized in this study. For this purpose, a sample of hundred and forty-one (141) Portuguese manufacturing organizations was used to gather the relevant information pertaining to the above dimensions. The conceptual framework in Figure 1 is used to guide this study. The framework presents the relevant variables being explored from an open system perspective of today's organization. In this context, information is viewed as the engine, which fuels the performance of the organization. Therefore, understanding the interactions of such information/business relationships has great practical value towards taking actions and deploying informational resources aimed at improving organizational performance. 


\section{RELEVANT LITERATURE AND RESEARCH HYPOTESES}

\subsection{The influence of IT-business alignment on organizational performance}

IT-business alignment has been reported as a major concern to IT and business executives (Abareshi, 2011; Ghosh, Troutt, \& Brandyberry, 2013; Luftman, Papp, \& Brier, 1999; Tallon \& Kraemer, 2003). According to the literature, IT-business alignment maturity tends to enhance the effectiveness of information systems (Chan, Huff, Barclay, \& Copeland, 1997), the organizational performance (Abareshi, Martin, \& Molla, 2012; Byrd, Lewis, \& Bryan, 2006; Luftman \& Kempaiah, 2007; Sabherwal \& Chan, 2001), and therefore, the competitive advantage of business organizations (Kearns \& Lederer, 2003).

IT-business alignment can be defined based on different dimensions (Chan \& Reich, 2007). The strategic dimension refers to the degree to which business and IT strategies are integrated and complement each other. The social dimension refers to the mutual understanding and commitment between business and IT executives. It focuses on the state in which business and IT executives share a common vision about the contribution of IT to the success of the business (Johnson \& Lederer, 2005; Reich \& Benbasat, 1996). In this context, the convergence of ideas and practices between business and IT experts, regarding the potential of information technology in supporting business activities, appears to promote IT innovations (Lind \& Zmud, 1991) and improve financial performance (Johnson \& Lederer, 2005). Thus:

\footnotetext{
H1 - IT-business social alignment positively influences organizational performance.
} 


\subsection{The influence of IT-Business relationship on the social dimension of the alignment}

According to literature, improving the relationship between the IT and the nonIT organizational resources should promote the IT-business alignment. In the process this tends to improve the organizational performance (Karahanna \& Preston, 2013; Kearns \& Lederer, 2003; Luftman \& Brier, 1999). One of the key requirements for the ITbusiness alignment is the existence of a strong relationship between IT and business executives (Chan \& Reich, 2007; Feeny, Edwards, \& Simpson, 1992).

Communication was identified as an important factor for the convergence of opinions, and mutual understanding regarding the role of IT within the organization (Johnson \& Lederer, 2005; Lind \& Zmud, 1991). The level of communication between IT and business executives appears to have a positive influence on the alignment of IT resources and activates with business goals and objectives (Reich \& Benbasat, 2000; Wagner \& Weitzel, 2012). Therefore, the increased frequency of communication between business and IT executives, utilizing a variety of communication channels, could improve the common understanding of the strategic role of IT in the organization (Johnson \& Lederer, 2005).

A close relationship between the IT and non-IT staff is a key factor for the ITbusiness alignment and could be enhanced with formal and/or informal structures (Karahanna \& Preston, 2013; Karimi, Bhattacherjee, Gupta, \& Somers, 2000; Luftman \& Brier, 1999). On one hand, the creation of IT steering committees may provide a way to improve the integration of technical/business knowledge and also IT-business coordination mechanisms (Bowen, Cheung, \& Rohde, 2007; Karimi et al., 2000; Nolan \& Mcfarlan, 2005; Teo \& King, 1997). As such, communication is ensured, and the mutual 
understanding of the IT role within the organization can be achieved. On the other hand, informal organizational structures based on trust can also improve the crosscommunication between IT and business executives. They can be even more important for the IT-business alignment than the existence of formal structures (Chan, 2002).

In this context, the IT executives' participation in business management and the business executives' participation in IT management are needed in order to improve the IT-business alignment, and to promote the utilization of information technologies in the development of the organizational strategy (Kearns \& Lederer, 2003). Thus:

H2 - IT executives' participation in business management processes positively influences the IT-business social alignment.

H3 - Business executives' participation in IT management processes positively influences the IT-business social alignment.

\subsection{Shared domain knowledge between IT and business executives}

The existence of a shared domain knowledge (SDK) between individuals of different backgrounds can influence their capacity to interact and transfer knowledge (Cohen \& Levinthal, 1990; Grant, 1996; Madhavan \& Grover, 1998). As such, the shared domain knowledge between business and IT staff can influence different dimensions of performance summarized below:

- The influence of SDK on the assimilation and use of IT (Armstrong \& Sambamurthy, 1999; Boynton, Zmud, \& Jacobs, 1994; Cereola et al., 2013).

- The influence of SDK on the alignment between IT and the business organization (Chan et al., 2006; Huang, 2010; Reich \& Benbasat, 2000).

- The influence of SDK on the rational planning of IT (Ranganathan \& Sethi, 2002). 
- The influence of SDK on the performance of the IS department (Chen \& Wu, 2011; Nelson \& Cooprider, 1996).

In this context, it seems that the cross-competences between IT and business executives can be an intangible competitive resource, which has the potential to improve the organizational performance.

According to Teo \& King (1997) business competences of IT executives can influence the level of integration between IT and business planning processes. Specific knowledge about the organizational processes should enable IT executives to understand the nature of the business which allows for a better IT-business alignment (Duncan, 1995; Huang, 2010; Reich \& Benbasat, 2000). Business competences of IT professionals can be a key factor in developing the relationship with business executives. These competences have the potential to enable IT professionals to better understand the business domain, business language, and interaction with their business partners (Bassellier \& Benbasat, 2004).

The IT knowledge of business executives allows them to better communicate with IT professionals. It helps business executives to better understand the strategic value of IT for the business organization (Bassellier, Benbasat, \& Reich, 2003; Boynton et al., 1994; Cereola et al., 2013). The business executives' knowledge of IT also increases the joint participation of IT and business executives in the organizational strategic planning processes, which improve the strategic alignment (Kearns \& Sabherwal, 2007). Thus:

H4 - Business competences of IT executives positively influence their participation in business management processes. 
H5 - Business competences of IT executives positively influence IT-business social alignment.

H6 - IT competences of business executives positively influence their participation in IT management processes.

H7 - IT competences of business executives positively influence IT-business social alignment.

\subsection{The influence of trust on IT-business relationship}

Trust between individuals or groups could be defined as the degree of reciprocal faith in others' intentions, behaviours, and skills towards organizational goals (Lee \& Choi, 2003). The development of trust between individuals with different characteristics and backgrounds provides a mechanism that enables them to work together and collaborate with each other more effectively (Mayer, Davis, \& Schoorman, 1995; Pinjani \& Palvia, 2013). As such, trust is essential to provide an appropriate environment for the creation and sharing of organizational knowledge (Nonaka, 1994).

Trust between individuals from different functional areas is strongly correlated with the extent of resources shared, which in turn promotes organizational innovation (Tsai \& Ghoshal, 1998). Trust can improve information sharing (Nahapiet \& Ghoshal, 1998; Papoutsakis \& Valles, 2006) and knowledge creation (Lee \& Choi, 2003).

The existence of trust between IT professionals and business managers can increase the shared knowledge between them, which can positively contribute to the IT overall performance (Nelson \& Cooprider, 1996; Wagner \& Weitzel, 2012). Thus:

H8 - Trust between IT and business executives positively influences the participation of IT executives in business management processes.

H9 - Trust between IT and business executives positively influences the participation of business executives in IT management processes. 
Overall, the literature reviewed above addresses some of the relevant relationships between business executives and their IT counterparts. However, most of the cited studies tend to examine such relationships discretely rather than collectively as a part of an open integrated organizational system. The nine hypotheses proposed in this research attempts to analyse these relationships from an open system organizational perspective. Such orientation takes the organizational culture and its impact on the potential of IT into consideration.

\section{METHODOLOGY}

\subsection{Instrument}

The research instrument used in this study has been designed based on an extensive literature review. The first phase of the instrument development included translation and adaptation to the Portuguese manufacturing environment. In the second phase, the instrument was presented to a panel of experts, including both practitioners and academicians. Special attention was paid to the use of terminologies and vocabulary consistent with the background of the participants. This objective was achieved after a few iterations.

For the purpose of this study, the final version of the research instrument is composed of forty-four (44) questions. These questions are organized in seven sections corresponding to the constructs identified from the literature (Table 2). For each of the questions included in the instrument, business executives were asked to give their opinion, using a 1 to 7 Likert-type scale.

\section{Insert table 2}




\subsection{Sample and data analysis}

For the purpose of this study, the sample used was obtained from the database maintained by the Statistics Portugal Official Agency. This database includes one thousand four hundred and ninety-eight (1498) manufacturing organizations with more than fifty (50) employees, and total revenue of five (5) million euros or more. The research instrument was sent to the Chief Financial Officers (CFO) of these organizations. The CFOs were chosen because they are in a better position to assess the organizational performance.

One hundred and forty one (141) responses were received from CFOs. The response rate was relatively low $(10.3 \%)$, but consistent with similar studies (Lin \& Pervan, 2003; Magal, Kosalge, \& Levenburg, 2009; Trigo, Varajão, Figueiredo, \& Barroso, 2007).

The participating executives were asked to provide information regarding sales revenue, number of employees, and industry type of their organizations (see Table 3). No significant differences were detected $(\chi=0.05)$ in terms of the characteristics of respondents relative to the non-respondents.

\section{Insert table 3}

Due to the nature of collected data, the common method variance was checked to verify the existence of problems with response-bias (Podsakoff, MacKenzie, Lee, \& Podsakoff, 2003). Harman's text was used for checking common method variance (Harman, 1976). The results suggested that common method variance was not a significant problem in the data set.

The data obtained from the participants was analysed using a structural equation modelling (SEM) approach. Both measurement and structural models were estimated 
using AMOS 19.0. The maximum likelihood was used as the estimation method. For the purpose of the SEM analysis, all relevant assumptions were verified and found to be satisfied.

Due to sample dimension and number, the variables analysed were aggregated based on content analysis. The parcels were obtained based on the average of the initial variables.

\section{RESULTS}

\subsection{The measurement model}

The psychometric properties of the instrument were checked in terms of unidimensionality, internal consistency, convergent and discriminant validity of each constructs. Table 4 presents the coefficients generated by the estimation of the measurement model and the goodness-of-fit measures most used by literature. All the estimated coefficients were found to be positive and statistically significant $(\chi=0.001)$. The existence of significance for the chi-square, the SRMR (0.068), the RMSEA (0.067), the CFI (0.98) and TLI (0.97) indicated a good fit of the model to the data (Hair, Black, Babin, \& Anderson, 2009; Hu \& Bentler, 1999).

\section{Insert table 4}

\subsection{Structural model}

The formulated hypotheses as well as other relationships between the constructs were tested using structural equation analysis. The results of the structural model are presented in Table 5. Among the considered constructs, IT-business social alignment was the only one, which showed a significant direct influence on 
organizational performance, as expected. However, these results give new insights regarding the main determinants of the IT-business social alignment.

\section{Insert table 5}

Based on the results of the structural model, the following hypotheses were rejected:

H4 - Business competences of IT executives positively influence their participation in business management processes.

H5 - Business competences of IT executives positively influence IT-business social alignment.

H7 - IT competences of business executives positively influence IT-business social alignment.

H8 - Trust between IT and business executives positively influences the participation of IT executives in business management processes.

\subsection{Discussion}

First, the shared domain knowledge between IT and business executives, only indirectly influences the IT-business social alignment. In fact, the direct paths from the IT competences of business executives, and from the business competences of IT executives both were not supported.

Second, the cross-participation of IT and business executives in the each other's management area positively influences IT-business social alignment. The results show a significant link between the business executives' participation in IT management and the IT executives' participation in business management. 
Third, the level of trust between the two types of executives directly influences IT-business social alignment, and also the participation of business executives in IT management. However, the same could not be detected with regard to the influence of trust on the participation of IT executives in business management. Therefore, hypothesis 8 was not supported.

The two constructs representing the shared domain knowledge, the IT competences of business executives and the business competences of IT executives, directly and positively influence the level of trust between the two types of executives. According to the results, the IT competences of business executives also influences their participation in IT management. However, the same did not hold true regarding IT executives. There was no significant influence detected regarding business competences of IT executives on their participation in business management. Therefore, hypothesis 4 was not supported. Finally, the results show a direct influence of the IT competences of business executives on the level of business competences of IT executives.

\section{CONCLUSION}

Using a sample of one hundred and forty-one (141) Portuguese business executives, this study attempted to explore the relevant relationships defining the interactions among the different elements of IT and business relations. Based on the results of the structural modelling analysis, the following conclusions are in order.

- IT- business relationship, operationalized in terms of the cross-participation of IT and business executives in the management of each other's area and also the mutual trust between them. 
- Shared domain knowledge, operationalized as the level of IT competences of business executives and business competences of IT executives.

- IT-business social alignment, operationalized as the shared vision about the contribution of IT to the business.

Shared domain knowledge between IT and business executives do not directly influence IT-business social alignment, contradicting the results obtained by (Reich \& Benbasat, 2000). However, an indirect influence through IT-business relationship was found. Shared domain knowledge positively influences the level of trust, which in turn leads to a better IT-business social alignment.

The cross-participation of IT executives and business executives in the management of the each other's area has also a direct positive impact on the social dimension of IT-business alignment. Kearns \& Lederer (2003) achieved similar results using the strategic dimension of alignment. According to the Portuguese executives, the IT competences of business executives also influence their participation in IT management. This finding confirms the results obtained by G. Bassellier et al. (2003) and by Kearns \& Sabherwal (2007). However, the results do not show the similar influence regarding IT executives. It appears that IT and business executives tend to play different roles in their interaction, which has not been explored by the literature.

This study identified two main determinants of the cross-participation of IT and business executives in each other's area: the shared domain knowledge and the level of trust between them. However, it seems that there is an asymmetry between IT executives and business executives. In fact, the results confirmed that higher levels of trust between IT and business executives, as well as the IT competences of business 
executives positively influence their participation in IT management. Nevertheless, in the case of the IT executives' participation in business management, none of the considered determinants was confirmed. Moreover, the IT executives' participation in business management is directly influenced by the business executive participation in IT management. It seems that business executives are leading the process of crossparticipation. When the business executives increase their level of participation in IT management, they also influence IT executives to increase their participation in business management.

The leading role of business executives can also be found in the shared domain knowledge. The results show that the level of IT competences of business executives directly and positively influences the level of business competences of IT executives. It seems that business executives with more skills in IT can attract IT professionals with more competences in business matters.

Previous studies have shown that trust between IT and business executives could increase the knowledge sharing (Pinjani \& Palvia, 2013) and information system performance (Nelson \& Cooprider, 1996), which promotes competitive advantage (Bhatt \& Grover, 2005). This study shows how it indirectly influences organizational performance. On one hand, it influences directly and positively the IT-business social alignment and indirectly the organizational performance. On the other hand, it appears to be a determinant factor to increase the business executives' participation in IT management. 


\section{IMPLICATIONS}

Overall, according to the surveyed Portuguese executives, it seems that trust between business and IT executives is one of the major drivers of improving social alignment, therefore, enhancing organizational performance. This influence is not only direct but also indirect, through the interaction between them. In this process, business executives should assume the leadership in order to promote this organizational interaction. Their participation in IT management leads to a greater participation of IT executives in business management and directly influences IT-business social alignment.

Finally, shared domain knowledge between IT and business executives influences their cross-participation in the each other's area and also influence the level of trust between them. Once again, business executives should lead this process, as those more technological skilled demand IT executives with higher levels of business competences.

In order to get the most value from IT, companies should promote crosscompetences between IT and business executives, develop a trust-based environment, and promote the cross-participation of them. The results point to the crucial role of business executives on the effective utilizations of these intangible resources. Their IT competences seem to promote their participation in IT management and attract IT managers to the sphere of business. In this context, it is important to emphasize the win-win nature of the relationship between these executives. Improving organizational performance provides the motivation for such a relationship.

This study has the limitations of the cross-section and survey-based research. Furthermore, all data was gathered from business executives of Portuguese manufacturing organizations. It is rather difficult to determine whether these results are 
generalizable to other organizational contexts and cultures. Perhaps future research should explore this issue.

Other studies are now required to analyse some issues of IT governance, related to the IT structure and decision rights along with the role of business executives in this field. It also evokes the need to study in depth the characteristics of the business executives, particularly those having more technological competences. Finally, it highlights the importance of better understanding the determinants of trust between IT and business executives. The open system perspective offered in Figure 1 could be expanded and validated by future studies. 


\section{REFERENCES}

Abareshi, A. (2011). The antecedents of IT-business alignment in manufacturing firms. International Journal of Business Information Systems, 8(3), 322-337.

Abareshi, A., Martin, W., \& Molla, A. (2012). The role of information and communication technologies in moving toward new forms of organising. International Journal of Business Information Systems, 9(2), 169-187.

Althonayan, A., \& Sharif, A. M. (2010). Aligning business and technology strategy within the airline industry. International Journal of Business Information Systems, 6(1), 79-94.

Armstrong, C. P., \& Sambamurthy, V. (1999). Information Technology Assimilation in Firms: The Influence of Senior Leadership and IT Infrastructures. Information Systems Research, 10(4), 304-327.

Barney, J. (1991). Firm Resources and Sustained Competitive Advantage. Journal of Management, 17(1), 99-120.

Bassellier, G., \& Benbasat, I. (2004). Business competence of information technology professionals: conceptual development and influence on IT-business partnerships. MIS Quarterly, 28(4), 673-694.

Bassellier, G., Benbasat, I., \& Reich, B. H. (2003). The Influence of Business Managers'IT Competence on Championing IT. Information Systems Research, 14(4), 317-336.

Bharadwaj, A. (2000). A resource-based perspective on information technology capability and firm performance: an empirical investigation. MIS Quarterly, 24(1), 169-196.

Bharadwaj, A., Sambamurthy, V., \& Zmud, R. W. (1999). IT capabilities: Theoretical perspectives and empirical operationalization. In Proceedings of the 20th international conference on Information Systems, ICIS 1999 (pp. 378-385). Charlotte, NC, United States.

Bhatt, G. D., \& Grover, V. (2005). Types of information technology capabilities and their role in competitive advantage: An empirical study. Journal of Management Information ..., 22(2), 253-277.

Bowen, P. L., Cheung, M.-Y. D., \& Rohde, F. H. (2007). Enhancing IT Governance Practices: A Model and Case Study of an Organization's Efforts. International Journal of Accounting Information Systems, 8(3), 191-221.

Boynton, A. C., Zmud, R. W., \& Jacobs, G. C. (1994). The influence of IT management practice on IT use in large organizations. MIS Quarterly, 18(3), 299-318. 
Byrd, T. A., Lewis, B. R., \& Bryan, R. W. (2006). The leveraging influence of strategic alignment on IT investment: An empirical examination. Information \& Management, 43(3), 308-321.

Byrd, T. A., \& Turner, D. E. (2000). Measuring the flexibility of information technology infrastructure: Exploratory analysis of a construct. Journal of Management Information Systems, 17(1), 167-208.

Cereola, S. J., Wier, B., \& Norman, C. S. (2013). Impact of top management team on firm performance in small and medium-sized enterprises adopting commercial open-source enterprise resource planning. Behaviour \& Information Technology, 31(9), 889-907.

Chan, Y. E. (2002). Why Haven't We Mastered Alignment? The Importance of the Informal Organization Structure. MIS Quarterly Executive, 1(2), 97-112.

Chan, Y. E., Huff, S. L., Barclay, D. W., \& Copeland, D. G. (1997). Business strategic orientation, information systems strategic orientation, and strategic alignment. Information Systems Research, 8(2), 125-150.

Chan, Y. E., \& Reich, B. H. (2007). IT alignment: what have we learned? Journal of Information Technology, 22(4), 297-315.

Chan, Y. E., Sabherwal, R., \& Thatcher, J. B. (2006). Antecedents and outcomes of strategic IS alignment: an empirical investigation. IEEE Transactions on Engineering Management, 53(1), 27-47.

Chao, C.-A., \& Chandra, A. (2012). Impact of owner's knowledge of information technology (IT) on strategic alignment and IT adoption in US small firms. Journal of Small Business and Enterprise Development, 19(1), 114-131.

Chen, Y.-C., \& Wu, J.-H. (2011). IT management capability and its impact on the performance of a CIO. Information \& Management, 48(4-5), 145-156.

Chung, S. H., Byrd, T. A., Lewis, B. R., \& Ford, F. N. (2005). An empirical study of the relationships between IT infrastructure flexibility, mass customization, and business performance. ACM SIGMIS Database, 36(3), 26-44.

Cohen, W. M., \& Levinthal, D. A. (1990). Absorptive capacity: A new perspective on learning and innovation. Administrative Science Quarterly, 35(1), 128-152.

Curry, M., Marshall, B., \& Kawalek, P. (2014). IT artifact bias: How exogenous predilections influence organizational information system paradigms. International Journal of Information Management, 34(4), 427-436.

Dehning, B., \& Richardson, V. J. (2002). Returns on investments in information technology: A research synthesis. Journal of Information Systems, 16(1), 7-30. 
Duncan, N. B. (1995). Capturing flexibility of information technology infrastructure: A study of resource characteristics and their measure. Journal of Management Information Systems, 12(2), 37-57.

Feeny, D. F., Edwards, B. R., \& Simpson, K. M. (1992). Understanding the CEO/CIO relationship. MIS Quarterly, 16(4), 435-448.

Feeny, D. F., \& Willcocks, L. P. (1998). Core IS capabilities for exploiting information technology. Sloan Management Review, 39(3), 9-21.

Ghosh, S., Troutt, M. D., \& Brandyberry, A. (2013). An RBV and real options-based soft OR heuristic for solution strategising. International Journal of Business Information Systems, 12(4), 404-422.

Goyal, D. P. (2012). Business alignment and critical success factors in information systems implementation: an empirical analysis of selected Indian organisations. International Journal of Business Information Systems, 10(4), 397-416.

Grant, R. M. (1996). Prospering in dynamically-competitive environments: organizational capability as knowledge Integration. Organization Science, 7(4), 375-387.

Hair, J., Black, W., Babin, B., \& Anderson, R. (2009). Multivariate data analysis (7th ed., p. 816). Prentice Hall.

Harman, H. H. (1976). Modern Factor Analysis (2nd ed., p. 487). Chicago, IL: University of Chicago Press.

Hu, L., \& Bentler, P. M. (1999). Cutoff criteria for fit indexes in covariance structure analysis: Conventional criteria versus new alternatives. Structural Equation Modeling: A Multidisciplinary Journal, 6(1), 1-55.

Huang, L. K. (2010). A Resource-based Analysis of IT Personnel Capabilities and Strategic Alignment. Journal of Research and Practice in Information Technology, 42(4), 263-287.

Johnson, A. M., \& Lederer, A. L. (2005). The Effect of Communication Frequency and Channel Richness on the Convergence between Chief Executive and Chief Information Officers. Journal of Management Information Systems, 22(2), 227252.

Karahanna, E., \& Preston, D. S. (2013). The Effect of Social Capital of the Relationship Between the $\mathrm{ClO}$ and Top Management Team on Firm Performance. Journal of Management Information Systems, 30(1), 15-56.

Karimi, J., Bhattacherjee, A., Gupta, Y. P., \& Somers, T. M. (2000). The effects of MIS steering committees on information technology management sophistication. Journal of Management Information Systems, 17(2), 207-230. 
Kearns, G. S., \& Lederer, A. L. (2003). A Resource-Based View of Strategic IT Alignment: How Knowledge Sharing Creates Competitive Advantage. Decision Sciences, 34(1), 1-29.

Kearns, G. S., \& Sabherwal, R. (2007). Strategic Alignment Between Business and Information Technology: A Knowledge-Based View of Behaviors, Outcome, and Consequences. Journal of Management Information Systems, 23(3), 129-162.

Keramati, A., \& Behmanesh, I. (2010). Assessing the impact of information technology on firm performance using canonical correlation analysis. International Journal of Business Information Systems, 6(4), 497-513.

Lee, H., \& Choi, B. (2003). Knowledge management enablers, processes, and organizational performance: An integrative view and empirical examination. Journal of Management Information Systems, 20(1), 179-228.

Lin, C., \& Pervan, G. P. (2003). The practice of IS/IT benefits management in large Australian organizations. Information \& Management, 41(1), 13-24.

Lind, M. R., \& Zmud, R. W. (1991). The Influence of a Convergence in Understanding Between Technology Providers and Users on Information Technology Innovativeness. Organization Science, 2(2), 195-217.

Luftman, J., \& Brier, T. (1999). Achieving and Sustaining Business-IT Alignment. California Management Review, 42(1), 109-122.

Luftman, J., \& Kempaiah, R. (2007). An Update on Business-IT Alignment: "A Line" has been Drawn. MiS Quarterly Executive, 6(3), 165-177.

Luftman, J., Papp, R., \& Brier, T. (1999). Enablers and Inhibitors of Business-IT Alignment. Communications of the Association for Information Systems, 1(11), 133.

Madhavan, R., \& Grover, R. (1998). From Embedded Knowledge to Embodied Knowledge : New Product Development as Knowledge Management. Journal of Marketing, 62(4), 1-12.

Magal, S. R., Kosalge, P., \& Levenburg, N. M. (2009). Using importance performance analysis to understand and guide e-business decision making in SMEs. Journal of Enterprise Information Management, 22(1/2), 137-151.

Masli, A., Richardson, V. J., Sanchez, J. M., \& Smith, R. E. (2011). Returns to IT excellence: Evidence from financial performance around information technology excellence awards. International Journal of Accounting Information Systems, 12(3), 189-205.

Mayer, R. C., Davis, J. H., \& Schoorman, F. D. (1995). An integrative model of organizational trust. Academy of Management Review, 20(3), 709-734. 
McLeod, A., \& Pippin, S. (2012). Toward multi-dimensional trust: exploring antecedents to trust in a complex domain. International Journal of Business Information Systems, 9(2), 222-238.

Nahapiet, J., \& Ghoshal, S. (1998). Social capital, intellectual capital, and the organizational advantage. Academy of Management Review, 23(2), 242-266.

Nelson, K. M., \& Cooprider, J. G. (1996). The Contribution of Shared Knowledge to IS Group Performance. MIS Quarterly, 20(4), 409-432.

Nolan, R. L., \& Mcfarlan, F. W. (2005). Information Technology and the Board of Directors. Harvard Business Review, 83(10), 96-106.

Nonaka, I. (1994). A Dynamic Theory of Organizational Knowledge Creation. Organization Science, 5(1), 14-37.

Papoutsakis, H., \& Valles, R. S. (2006). Linking Knowledge Management and Information Technology to Business Performance: A Literature Review and a Proposed Model. Journal of Knowledge Management Practice, 7(1), 1-12.

Peppard, J., \& Ward, J. (2004). Beyond strategic information systems: towards an IS capability. Journal of Strategic Information Systems, 13(2), 167-194.

Pinjani, P., \& Palvia, P. (2013). Trust and knowledge sharing in diverse global virtual teams. Information \& Management, 50(4), 144-153.

Podsakoff, P. M., MacKenzie, S. B., Lee, J.-Y., \& Podsakoff, N. P. (2003). Common method biases in behavioral research: a critical review of the literature and recommended remedies. The Journal of Applied Psychology, 88(5), 879-903.

Preston, D., Karahanna, E., \& Rowe, F. (2006). Development of shared understanding between the Chief Information officer and top management team in U.S. and French Organizations: a cross-cultural comparison. IEEE Transactions on Engineering Management, 53(2), 191-206.

Ranganathan, C., \& Sethi, V. (2002). Rationality in Strategic Information Technology Decisions: The Impact of Shared Domain Knowledge and IT Unit Structure. Decision Sciences, 33(1), 59-86.

Ravichandran, T., \& Lertwongsatien, C. (2005). Effect of information systems resources and capabilities on firm performance: a resource-based perspective. Journal of Management Information Systems, 21(4), 237-276.

Reich, B. H., \& Benbasat, I. (1996). Measuring the Linkage between Business and Information Technology Objectives. MIS Quarterly, 20(1), 55-81. 
Reich, B. H., \& Benbasat, I. (2000). Factors that influence the social dimension of alignment between business and information technology objectives. MIS Quarterly, 24(1), 81-113.

Rockart, J. F., Earl, M. J., \& Ross, J. W. (1996). Eight imperatives for the new IT organization. Sloan Management Review, 38(1), 43-56.

Ross, J. W., Beath, C. M., \& Goodhue, D. L. (1996). Develop long-term competitiveness through IT assets. Sloan Management Review, 38(1), 31-42.

Sabherwal, R., \& Chan, Y. E. (2001). Alignment between business and IS strategies: a study of prospectors, analyzers, and defenders. Information Systems Research, 12(1), 11-33.

Siurdyban, A., Svejvig, P., \& Møller, C. (2012). A design perspective on aligning processcentric and technology-centric approaches. International Journal of Business Information Systems, 11(2), 215-234.

Tallon, P., \& Kraemer, K. (2003). Investigating the relationship between strategic alignment and IT business value: the discovery of a paradox. In Creating business value with information technology: challenges and solutions (Vol. 12). IGI Publishing Hershey, PA, USA.

Teo, T. S. H., \& King, W. R. (1997). Integration between business planning and information systems planning: An evolutionary-contingency perspective. Journal of Management Information Systems, 14(1), 185-214.

Trigo, A., Varajão, J., Figueiredo, N., \& Barroso, J. (2007). Information Systems and Technology Adoption by the Portuguese Large Companies. In Proceedings of the 13rd European and Mediterranean Conference on Information Systems, EMCIS 2007.

Tsai, W., \& Ghoshal, S. (1998). Social Capital and Value Creation: The Role of Intrafirm Networks. Academy of Management Journal, 41(4), 464-476.

Van den Hooff, B., \& de Winter, M. (2011). Us and them: a social capital perspective on the relationship between the business and IT departments. European Journal of Information Systems, 20(3), 255-266.

Wade, M., \& Hulland, J. (2004). The Resource-Based View and Information Systems Research: Review, Extension, and Suggestions for Future Research. MIS Quarterly, 28(1), 107-142.

Wagner, H., \& Weitzel, T. (2012). How to Achieve Operational Business-IT Alignment: Insights from a Global Aerospace Firm. MIS Quarterly Executive, 11(1), 25-36. 
Table 1 - Survey-based studies reviewed with IT-business interaction variables

\begin{tabular}{|c|c|c|c|c|}
\hline Article Constructs & IT-Business relationship & Shared domain knowledge & IT-business social alignment & Organizational performance \\
\hline (Armstrong \& Sambamurthy, 1999) & ----- & $\begin{array}{l}\mathrm{ClO} \text { business knowledge; TMT } \\
\text { IT knowledge }\end{array}$ & ----- & IT assimilation \\
\hline (Bassellier et al., 2003) & ----- & $\begin{array}{l}\text { Business Managers' IT } \\
\text { competence }\end{array}$ & ----- & ----- \\
\hline (Bassellier \& Benbasat, 2004) & ----- & $\begin{array}{l}\text { Business Competence of IT } \\
\text { professionals }\end{array}$ & ----- & ----- \\
\hline (Bhatt \& Grover, 2005) & Relationship infrastructure & IT Business Expertise & ----- & Competitive advantage \\
\hline (Boynton et al., 1994) & $\begin{array}{ll}---- \\
\end{array}$ & Managerial IT knowledge & $\begin{array}{ll}---- \\
\end{array}$ & $\begin{array}{c}----\mathrm{V} \\
\end{array}$ \\
\hline (Chan et al., 2006) & $\begin{array}{ll}---- \\
\end{array}$ & Shared Domain knowledge & $\begin{array}{ll}---- \\
\end{array}$ & Organizational success \\
\hline (Johnson \& Lederer, 2005) & $\begin{array}{l}\text { Communication frequency } \\
\text { and richness }\end{array}$ & ----- & $\begin{array}{l}\text { Convergence about the } \\
\text { future role of IT }\end{array}$ & ----- \\
\hline (Karimi et al., 2000) & Steering Committees Roles & ----- & $\begin{array}{ll}---- \\
\end{array}$ & ----- \\
\hline (Kearns \& Lederer, 2003) & $\begin{array}{l}\text { The CIO participates in } \\
\text { business planning; The CEO } \\
\text { participates in IT planning }\end{array}$ & ----- & ----- & $\begin{array}{l}\text { IT is used for competitive } \\
\text { advantage }\end{array}$ \\
\hline (Kearns \& Sabherwal, 2007) & $\begin{array}{l}\text { IT manager's participation in } \\
\text { business planning; Business } \\
\text { manager's participation in } \\
\text { strategic IT planning }\end{array}$ & $\begin{array}{l}\text { Top manager's knowledge of } \\
\text { IT }\end{array}$ & ----- & Business impact of IT \\
\hline (Nelson \& Cooprider, 1996) & Mutual Trust & Shared knowledge & ----- & IS performance \\
\hline (Ranganathan \& Sethi, 2002) & $\begin{aligned}---- \\
\end{aligned}$ & Shared domain knowledge & $\begin{array}{ll}---- \\
\end{array}$ & \\
\hline $\begin{array}{l}\text { (Ravichandran \& Lertwongsatien, } \\
\text { 2005) }\end{array}$ & IS partnership quality & IS Human capital & ----- & Firm performance \\
\hline (Reich \& Benbasat, 2000) & $\begin{array}{l}\text { Communication between IT } \\
\text { and business managers }\end{array}$ & Shared domain knowledge & Social alignment & ----- \\
\hline (Teo \& King, 1997) & ----- & IS competence & ----- & ----- \\
\hline
\end{tabular}


Table 2 - Constructs operationalization

\begin{tabular}{|l|l|}
\hline \multicolumn{1}{|c|}{ Constructs } & \multicolumn{1}{c|}{ Literature support } \\
\hline Business competences of IT professionals & $\begin{array}{l}\text { (Byrd \& Turner, 2000), (Bassellier \& } \\
\text { Benbasat, 2004); (Chung, Byrd, Lewis, } \\
\text { \& Ford, 2005) }\end{array}$ \\
\hline IT competences of business executives & $\begin{array}{l}\text { (Bassellier et al., 2003); (Kearns \& } \\
\text { Sabherwal, 2007) }\end{array}$ \\
\hline $\begin{array}{l}\text { IT executives' participation in the business } \\
\text { management }\end{array}$ & (Kearns \& Lederer, 2003) \\
\hline Business executives' participation in IT management & $\begin{array}{l}\text { (Kearns \& Lederer, 2003); (Bassellier } \\
\text { et al., 2003) }\end{array}$ \\
\hline Trust between IT and business executives & (Lee \& Choi, 2003) \\
\hline IT-Business social alignment & (Preston, Karahanna, \& Rowe, 2006) \\
\hline Organizational performance & (Lee \& Choi, 2003) \\
\hline
\end{tabular}

Table 3 - Respondent profile

\begin{tabular}{|c|c|c|}
\hline Item & Frequency & Percentage \\
\hline Manufacturing Industries & \multirow[b]{2}{*}{9} & \multirow[b]{2}{*}{$6.4 \%$} \\
\hline Food products, beverages and tobacco & & \\
\hline Textiles and textile products & 16 & $11.3 \%$ \\
\hline Leather and leather products & 4 & $2.8 \%$ \\
\hline Wood and wood products & 6 & $4.3 \%$ \\
\hline Pulp, paper and paper products; publishing and printing & 9 & $6.4 \%$ \\
\hline Chemical products, chemical products and man-made fibers & 10 & $7.1 \%$ \\
\hline Rubber articles and plastic products & 6 & $4.3 \%$ \\
\hline Other non-metallic mineral products & 10 & $7.1 \%$ \\
\hline Basic metals and fabricated metal products & 19 & $13.5 \%$ \\
\hline Machinery and equipment n.e.c. & 5 & $3.5 \%$ \\
\hline Electrical and optical equipment & 9 & $6.4 \%$ \\
\hline Transport equipment & 8 & $5.7 \%$ \\
\hline Industry, n.e.c.* & 3 & $2.1 \%$ \\
\hline \multirow[t]{2}{*}{ Not reported } & 27 & $19.1 \%$ \\
\hline & 141 & $100.0 \%$ \\
\hline Sales revenue $(.000 €)$ & \multirow[b]{2}{*}{68} & \multirow[b]{2}{*}{$48.2 \%$} \\
\hline From 5.000 to 15.000 & & \\
\hline 15.001 to 40.000 & 28 & $19.9 \%$ \\
\hline More than 40.000 & 22 & $15.6 \%$ \\
\hline \multirow[t]{2}{*}{ Not reported } & 23 & $16.3 \%$ \\
\hline & 141 & $100.0 \%$ \\
\hline Number of employees & \multirow[b]{2}{*}{45} & \multirow[b]{2}{*}{$31.9 \%$} \\
\hline From 50 to 99 & & \\
\hline From 100 to 250 & 60 & $42.6 \%$ \\
\hline More than 250 & 18 & $12.8 \%$ \\
\hline \multirow[t]{2}{*}{ Not reported } & 18 & $12.8 \%$ \\
\hline & 141 & $100.0 \%$ \\
\hline
\end{tabular}

* Industry, n.e.c. includes industries with less than three occurrences. 
Table 4 - Estimates of the measurement model

\begin{tabular}{|c|c|c|c|c|}
\hline Construct & Items/parcels & $\begin{array}{l}\text { Standard. } \\
\text { loadings }\end{array}$ & t-value & $\mathbf{R}^{2}$ \\
\hline \multirow{3}{*}{$\begin{array}{l}\text { Business competences of } \\
\text { IT professionals } \\
\alpha=0.91 ; \mathrm{cr}=0.91 ; \text { ave }=78 \%\end{array}$} & - Business processes knowledge & 0.84 & 12.13 & 0.71 \\
\hline & - Effective working in cross-functional teams & 0.93 & 14.18 & 0.87 \\
\hline & - Effective problem solving & 0.87 & 12.77 & 0.76 \\
\hline \multirow{3}{*}{$\begin{array}{l}\text { IT competence of } \\
\text { Business executives } \\
\alpha=0.91 ; \mathrm{cr}=0.91 ; \text { ave }=77 \%\end{array}$} & - IT and IS knowledge & 0.84 & 12.06 & 0.71 \\
\hline & - IT project and management & 0.89 & 13.22 & 0.80 \\
\hline & - IT management experience & 0.89 & 13.12 & 0.79 \\
\hline \multirow[t]{3}{*}{$\begin{array}{l}\text { IT executives' participation in } \\
\text { business management }\end{array}$} & $\begin{array}{l}\text { - Regular attendance of business planning } \\
\text { meetings }\end{array}$ & 0.96 & 14.91 & 0.92 \\
\hline & $\begin{array}{l}\text { - Contribution to the formulation of business } \\
\text { goals }\end{array}$ & 0.93 & 14.31 & 0.87 \\
\hline & - Regular informal contacts with top management & 0.73 & 9.90 & 0.53 \\
\hline \multirow{3}{*}{$\begin{array}{l}\text { Business executives' } \\
\text { participation in IT } \\
\text { management } \\
\alpha=0.96 ; \mathrm{cr}=0.96 \text {; ave }=88 \%\end{array}$} & - Active player on IT decisions & 0.93 & 14.52 & 0.87 \\
\hline & - Promote the strategic utilization of IT & 0.92 & 14.26 & 0.85 \\
\hline & $\begin{array}{l}\text { - Promote the relationship between IT and non-IT } \\
\text { people }\end{array}$ & 0.96 & 15.19 & 0.91 \\
\hline \multirow{3}{*}{$\begin{array}{l}\text { Trust between IT and business } \\
\text { executives } \\
\alpha=0.98 ; \mathrm{cr}=0.98 \text {; ave }=95 \%\end{array}$} & - Reciprocal faith in others' ability & 0.96 & 15.58 & 0.93 \\
\hline & $\begin{array}{l}\text { - Reciprocal faith in others' intentions and } \\
\text { behaviours }\end{array}$ & 0.99 & 16.23 & 0.97 \\
\hline & $\begin{array}{l}\text { - Reciprocal faith in others' working toward } \\
\text { organizational goals }\end{array}$ & 0.97 & 15.80 & 0.94 \\
\hline \multirow[t]{4}{*}{ IT-Business social alignment } & $\begin{array}{l}\text { - Shared understanding of the role of IS in the } \\
\text { organization }\end{array}$ & 0.89 & 13.25 & 0.78 \\
\hline & $\begin{array}{l}\text { - Shared view of the role of IS as a competitive } \\
\text { weapon for the organization }\end{array}$ & 0.90 & 13.65 & 0.81 \\
\hline & $\begin{array}{l}\text { - Shared understanding of how IS can be used to } \\
\text { increase productivity of organization's operation }\end{array}$ & 0.91 & 13.85 & 0.83 \\
\hline & $\begin{array}{l}\text { - Common view regarding the prioritization of IS } \\
\text { investments }\end{array}$ & 0.86 & 12.56 & 0.74 \\
\hline \multirow[t]{5}{*}{ Organizational performance } & - Business success & 0.84 & 11.56 & 0.70 \\
\hline & - Market share & 0.64 & 8.02 & 0.41 \\
\hline & - Growing rate & 0.84 & 11.73 & 0.71 \\
\hline & - Profitability & 0.71 & 9.15 & 0.50 \\
\hline & - Innovation & 0.69 & 8.79 & 0.47 \\
\hline
\end{tabular}

Notes: $\chi^{2}=378.1(p=.00) ; \chi^{2} / d f=1.64, d f=231, S R M R=0.068, P N F I=0.79$, TLI $(S-B)=0.97$,

IFI $(S-B)=0.98, C F I(S-B)=0.98$, and RMSEA $(S-B)=0.067$. 
Table 5 - Significant paths between the constructs

\begin{tabular}{|c|c|c|c|}
\hline & & Coefficient & SMC \\
\hline IT-business social alignment & Organizational performance & $0.31 * * *$ & 0.10 \\
\hline $\begin{array}{l}\text { IT executives' participation in } \\
\text { business management }\end{array}$ & IT-business social alignment & $0.18 * *$ & \multirow{3}{*}{0.71} \\
\hline $\begin{array}{l}\text { Business executives' } \\
\text { participation in IT management }\end{array}$ & IT-business social alignment & $0.37 * * *$ & \\
\hline $\begin{array}{l}\text { Trust between IT and business } \\
\text { executives }\end{array}$ & IT-business social alignment & $0.45 * * *$ & \\
\hline $\begin{array}{l}\text { IT competences of business } \\
\text { executives }\end{array}$ & $\begin{array}{l}\text { Business executives' } \\
\text { participation in IT management }\end{array}$ & $0.46 * * *$ & \multirow{2}{*}{0.54} \\
\hline $\begin{array}{l}\text { Trust between IT and business } \\
\text { executives }\end{array}$ & $\begin{array}{l}\text { Business executives' } \\
\text { participation in IT management }\end{array}$ & $0.37 * * *$ & \\
\hline $\begin{array}{l}\text { Business executives' } \\
\text { participation in IT management }\end{array}$ & $\begin{array}{l}\text { IT executives' participations in } \\
\text { business management }\end{array}$ & $0.55 * * *$ & 0.31 \\
\hline $\begin{array}{l}\text { Business competences of IT } \\
\text { executives }\end{array}$ & $\begin{array}{l}\text { Trust between IT and business } \\
\text { executives }\end{array}$ & $0.42 * * *$ & \multirow{2}{*}{0.40} \\
\hline $\begin{array}{l}\text { IT competences of business } \\
\text { executives }\end{array}$ & $\begin{array}{l}\text { Trust between IT and business } \\
\text { executives }\end{array}$ & $0.32 * * *$ & \\
\hline $\begin{array}{l}\text { IT competences of business } \\
\text { executives }\end{array}$ & $\begin{array}{l}\text { Business competences of IT } \\
\text { executives }\end{array}$ & $0.62 * * *$ & 0.38 \\
\hline
\end{tabular}

Notes: $* * * p<0.001 ; * * p<0.01 ; * p<0.05$ 
Figure 1- An open system organizational performance perspective on the dynamic relationship between IT and business

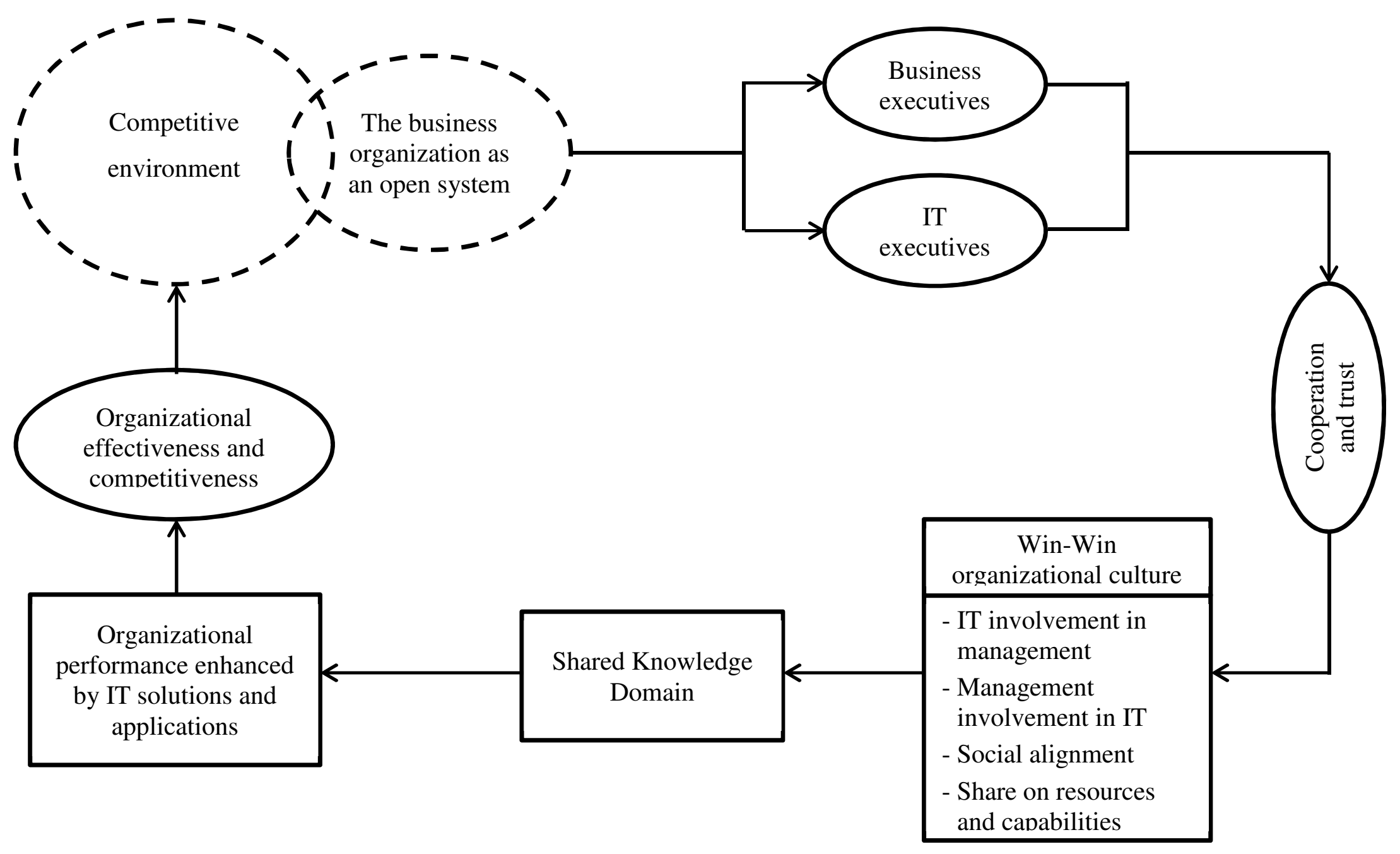

